\title{
KARAKTERISTIK VEGETASI DI HUTAN ALAM DATARAN RENDAH, HUTAN TANAMAN, DAN LAHAN PASCA TAMBANG NIKEL DI KABUPATEN BOMBANA
}

\author{
Vegetation Characteristics in Lowland Natural Forest, Plantation Forest, and Post Nickel \\ Mining Land in Bombana District
}

\author{
Ardiyansyah Purnama ${ }^{1}$, Basuki Wasis ${ }^{2}$, dan Iwan Hilwan ${ }^{2}$
}

(Diterima Agustus 2019/Disetujui November 2019)

\begin{abstract}
Nickel mining in Bombana District is one of the mining activities which generates a very large income for the area. However, mining carried out continuously will certainly cause the environment to be damaged, especially soils and vegetation when mining activities end. Good management of post-mining land is one of the obligations of the mining business unit. Management can include reclamation and replanting land so that exposed land can be reforested. Reforesting ex-mining land is not easy. These efforts need to be carried out with comprehensive treatment concerning the improvement of the vegetation composition as well as the physical, chemical, and biological aspects of the soil used so that the greening plants that are introduced can adapt well. The purpose of this study is to identify and compare the characteristics of vegetation and soil in lowland natural forests, plantations and post-nickel mining in Bombana District. In this study, observations were made at three different locations to look for differences in characteristics caused by the existence of nickel mining activities. From the results of the study showed that there was a decrease in the composition of vegetation due to changes from natural forest to plantations. In addition, the level of soil fertility is also declining due to land clearing for mining.
\end{abstract}

Key words : nickel, mining, Bombana, soil, vegetation

\section{PENDAHULUAN}

Sulawesi Tenggara memiliki potensi sumber daya bahan tambang yang melimpah, terutama nikel. Berdasarkan jumlah Izin Usaha Pertambangan (IUP) yang diterbitkan, yaitu sebanyak 528 IUP, sebanyak 350 atau $66 \%$ diantaranya adalah IUP tambang nikel. Hal ini menunjukan bahwa kegiatan pertambangan di Provinsi Sulawesi Tenggara didominasi oleh kegiatan pertambangan nikel. Luas sebaran endapan nikel diperkirakan mencapai 480032.13 ha (ESDM 2015).

Salah satu kabupaten yang memiliki potensi cadangan nikel yang cukup besar adalah Kabupaten Bombana. Kabupaten Bombana merupakan salah satu kabupaten yang ada di Provinsi Sulawesi Tenggara hasil pemekaran dari Kabupaten Buton pada Tahun 2003. Sektor pertambangan nikel di Kabupaten Bombana merupakan salah satu sektor yang mendapat perhatian cukup serius dari pemerintah daerah. Hal ini, disebabkan sektor pertambangan memberikan pendapatan yang relatif besar bagi kabupaten ini. Potensi cadangan nikel di Kabupaten Bombana mencapai 28.2 miliar wmt dan menjadi terbesar kedua setelah Kabupaten Konawe Utara (ESDM 2015).

Kegiatan pertambangan nikel merupakan kegiatan

\footnotetext{
${ }^{1}$ Program Studi Silvikultur Tropika, Sekolah Pascasarjana, Institut Pertanian Bogor

* Penulis korespondensi:

E-mail: ardiyansyah_purnama@apps.ipb.ac.id

2 Departemen Silvikultur, Fakultas Kehutanan, Institut Pertanian Bogor
}

eksploitasi sumberdaya alam tidak terbarukan (nonrenewable resources) yang diawali dengan pembukaan atau konversi lahan menjadi kawasan pertambangan maka ini dapat menjadi sumber terjadinya kerusakan bentang lahan yang biasanya berupa hilangnya vegetasi di atas areal pertambangan tersebut (Ahmad 2009). Hilangnya vegetasi berakibat pada penurunan bahan organik (Indrayatie 2011) dan penurunan unsur hara sehingga akan menurunkan produktivitas lahan (Yudhistira 2011).

Dalam penambangan terbuka, karena metodanya membuka lapisan atas tanah ketika penambangan bahan galian dilakukan, pengelolaan perlu direncanakan dengan baik agar lingkungan dan sumber daya alam lainnya tidak terganggu. Hal ini untuk mencegah lahan yang menjadi tandus dan miskin hara, rawan terhadap bahaya erosi dan hilangnya plasma nutfah pada lahan tersebut (Widiatmaka et al. 2010).

Pengelolaan secara baik lahan pasca-tambang merupakan salah satu kewajiban unit usaha pertambangan. Pengelolaan antara lain dapat berupa reklamasi dan penanaman kembali lahan sehingga tanah yang tersingkap dapat dihijaukan kembali. Sayangnya, hampir seluruh areal reklamasi yang telah dibangun malah tersusun dari jenis pionir dan bukan jenis endemik setempat sehingga dapat berdampak pada hilangnya keaslian dari kawasan tersebut. Berdasarkan hal tersebut perlu dilakukan penelitian tentang karakteristik vegetasi di areal tersebut menjadi penting untuk dilakukan. Hasil penelitian ini dapat menjadi baseline bagi pemerintah setempat dalam menanggulangi keadaan hutan yang ada. 


\section{METODE PENELITIAN}

\section{Waktu dan Tempat}

Penelitian ini dilaksanakan dari bulan Februari sampai April 2017, bertempat di hutan alam dataran rendah, hutan tanaman, dan lahan pasca tambang nikel di Kabupaten Bombana, Provinsi Sulawesi Tenggara.

\section{Alat dan Bahan}

Alat yang digunakan dalam penelitian ini adalah GPS (Global Positioning System), kompas, meteran (panjang $50 \mathrm{~m}$ ), klinometer, kaliper, parang/golok, tambang, tali rafia, plastik bening, kertas label, tongkat dbh $1.3 \mathrm{~m}$, patok, alat tulis, dan kamera. Adapun bahan yang digunakan adalah koran, tally sheet, dan vegetasi di hutan alam dataran rendah, hutan tanaman, dan lahan pasca tambang di Kabupaten Bombana.

\section{Prosedur Penelitian}

\section{Pembuatan Plot Contoh}

Lokasi penelitian ditentukan secara purposive sampling yaitu menggunakan stratifikasi berdasarkan tutupan lahan (land cover) (BSN 2011). Stratifikasi pada lokasi penelitian dilakukan berdasarkan kondisi tutupan lahannya, yang dibagi menjadi tiga lokasi yaitu areal hutan alam dataran rendah (lokasi 1), hutan tanaman (lokasi 2), dan lahan pasca tambang nikel (lokasi 3) sebanyak 5 plot pada setiap lokasi.

\section{Areal Hutan Alam Dataran Rendah}

Pada lokasi ini, dibuat petak contoh berukuran 100 m x 20 m sebanyak 5 jalur dengan jarak antar jalur adalah $100 \mathrm{~m}$ pada lokasi terpilih dengan metode kombinasi antara jalur dan garis berpetak (Indriyanto 2008). Pengambilan petak contoh dari jalur tersebut dibagi ke dalam petak-petak pengamatan yang lebih kecil (nested sampling) dengan pembagian yaitu pohon $(20 \mathrm{~m} \times 20 \mathrm{~m})$, tiang $(10 \mathrm{~m} \times 10 \mathrm{~m})$, pancang $(5 \mathrm{~m} \times 5$ $\mathrm{m})$, semai dan tumbuhan bawah (2 m x $2 \mathrm{~m}$ ) (Bismark 2011). Penempatan unit contoh dilakukan dengan teknik sampling systematic sampling with random starts yaitu peletakan petak ukur pertama dilakukan secara acak dan petak ukur berikutnya diletakan secara sistematik.

\section{Areal Hutan Tanaman}

Jenis pohon yang diukur pada hutan tanaman ini adalah sengon. Oleh karena jenisnya yang homogen maka pengumpulan data dilakukan dengan menggunakan metode plot lingkaran. Pada lokasi tersebut dibuat plot lingkaran seluas 0.1 ha dengan jarijari $17.84 \mathrm{~m}$. Data yang diambil pada plot tersebut adalah data pohon meliputi jenis, diameter, dan tinggi pohon. Pada petak $1 \mathrm{~m}$ x $1 \mathrm{~m}$ data yang diambil adalah data tumbuhan bawah meliputi jenis dan jumlah individu tiap jenisnya.

\section{Struktur Hutan}

Struktur tegakan yang diamati dalam penelitian ini, yaitu struktur vertikal (stratifikasi tajuk) dan horisontal (sebaran diameter pohon). Cara untuk mengetahui struktur vertikal hutan, setiap individu pohon yang dijumpai di dalam petak ukur dan dikelompokkan berdasarkan kelas tinggi atau lapisan tajuk. Menurut Soerianegara \& Indrawan (1998), lapisan stratum terdiri dari lapisan A (>30 m), B (20-30 m), C (4-20 m), D (1-4 m). Adapun struktur horisontal untuk mengetahui penyebaran diameter pohon di hutan (struktur horisontal), maka setiap individu yang dijumpai di dalam petak ukur dikelompokkan dalam 7 kelas diameter, yaitu <10 cm; 10-19.9 cm; 20-29.9 cm; $30-39.9 \mathrm{~cm}$; 40-49.9 cm; 50-59.9 cm; dan $60 \mathrm{~cm}$ atau lebih.

\section{Analisis Data}

\section{Indeks Nilai Penting}

Data jumlah spesies pada setiap plot digunakan untuk menghitung frekuensi, data jumlah pohon setiap spesies digunakan untuk mengetahui tingkat kerapatan, dan data diameter batang (dbh) untuk mengetahui luas bidang dasar masing-masing spesies. Dari jumlah relatif ketiga variabel tersebut ditetapkan nilai penting masingmasing spesies pohon. Perhitungannya dilakukan dengan menggunakan rumus Soerianegara dan Indrawan (1988): INP $=\mathrm{FR}+\mathrm{KR}+\mathrm{DR}$, di mana INP = Indeks Nilai Penting; FR = Frekuensi Re-latif; KR = Kerapatan Relatif; dan DR = Dominansi Relatif. Semakin tinggi nilai penting suatu spesies, semakin tinggi pula tingkat penguasaannya di dalam komunitas yang bersangkutan.

\section{Indeks Keanekaragaman Jenis}

Keanekaragaman jenis tumbuhan ditentukan dengan menggunakan Indeks Keanekaragaman Shannon (Ludwig \& Reynolds 1988) dengan rumus:

$$
\mathrm{H}^{\prime}=-\sum_{\mathrm{i}=1}^{\mathrm{s}} \frac{\mathrm{n}_{\mathrm{i}}}{\mathrm{N}} \ln \frac{\mathrm{n}_{\mathrm{i}}}{\mathrm{N}}
$$

Keterangan:

$\mathrm{H}^{\prime} \quad$ = Indeks keanekaragaman jenis Shannon

$\mathrm{n}_{\mathrm{i}}=$ Jumlah individu suatu jenis ke-i dalam plot

$\mathrm{N}=$ Jumlah seluruh individu

$\mathrm{S} \quad=$ Jumlah jenis ditemukan

Indeks Kemerataan Jenis

Kemerataan jenis digunakan untuk mengetahui gejala dominansi diantara setiap jenis dalam suatu lokasi. Rumus yang digunakan untuk menghitung nilai Evennes (Ludwig \& Reynolds 1988). Nilai E yang mendekati satu menunjukkan distribusi jumlah individu setiap spesies hampir sama. Adapun rumus yang digunakan adalah sebagai berikut:

$$
E=\frac{H^{\prime}}{\ln (S)}
$$

Keterangan:

$\mathrm{E} \quad=$ Indeks kemerataan jenis

$\mathrm{H}^{\prime} \quad$ Indeks keanekaragaman jenis

$\mathrm{S} \quad=$ Jumlah jenis yang ditemukan 


\section{Indeks Kekayaan Jenis}

Kekayaan jenis diukur dengan menggunakan Indeks Margalef (Magurran 1988), yaitu:

$$
\mathrm{R}=\frac{\mathrm{S}-1}{\ln (\mathrm{N})}
$$

Keterangan:

$\mathrm{R} \quad=$ Indeks kekayaan jenis

$\mathrm{S} \quad=$ Jumlah jenis yang ditemukan

$\mathrm{N}$ = Jumlah seluruh individu

\section{Indeks Dominansi Jenis}

Indeks Dominansi Jenis bertujuan untuk mengetahui penguasaan suatu jenis pada suatu areal dengan rumus (Magurran 1988) sebagai berikut:

$$
C=-\sum_{\mathrm{i}=1}^{\mathrm{s}}\left(\frac{\mathrm{n}_{\mathrm{i}}}{\mathrm{N}}\right)^{2}
$$

Keterangan:

$\mathrm{C} \quad=$ Indeks dominansi jenis

$\mathrm{n}_{\mathrm{i}} \quad=$ Total kerapatan jenis ke-i

$\mathrm{N}=$ Total kerapatan

$\mathrm{s} \quad=$ Jumlah jenis yang ditemukan

Nilai indeks dominansi berkisar antara $0 \leq \mathrm{C} \leq 1$, apabila nilai $\mathrm{C}$ mendekati 1 maka akan mengindikasikan bahwa dalam suatu areal tertentu dikuasai oleh satu jenis saja. Sebaliknya, apabila nilai C mendekati 0 maka tidak terjadi pemusatan jenis atau terdapat beberapa jenis mendominasi secara bersamasama.

\section{HASIL DAN PEMBAHASAN}

\section{Komposisi dan Struktur Vegetasi}

Tipe hutan yang diamati pada penelitian ini adalah hutan alam dan hutan tanaman. Hutan alam di lokasi penelitian ini termasuk hutan alam dataran rendah, sedangkan hutan tanaman yang diamati adalah hutan tanaman sengon. Untuk melihat komposisi vegetasi pada maka dapat dilihat pada Tabel 1.

Berdasarkan data pada Tabel 1, pada lokasi hutan alam didominasi oleh semai dan pancang sedangkan pada lokasi hutan tanaman didominasi oleh pancang dan tiang. Jenis-jenis yang mendominasi pada lokasi hutan alam antara lain Tetracera scandens pada tingkat tumbuhan bawah, Planchonella firma pada tingkat

Tabel 1 Komposisi vegetasi pada lokasi pengamatan pancang, dan Schima walichii pada tingkat semai, tiang, dan pohon. Untuk lokasi hutan tanaman didominasi oleh jenis Falcataria moluccana pada tingkat pancang dan tiang. Untuk mengetahui tingkat dominansi spesies pada lokasi pengamatan dapat dilihat pada Gambar 1.

Pada Gambar 1 disajikan indeks nilai penting (INP) yang merupakan parameter yang digunakan untuk mengetahui tingkat dominansi spesies dalam suatu komunitas tumbuhan (Indriyanto 2006). Pada Gambar 1 tersebut menunjukkan nilai INP 6 jenis tertinggi pada setiap tingkat pertumbuhan. Pada tingkat semai dan tumbuhan bawah, jenis yang memiliki INP tertinggi berturut-turut dari yang terbesar adalah $T$. scandens, $K$. celebicum, rotan, S. wallichii, D. hispida, dan $U$. littolaris. Pada tingkat pancang, jenis yang jenis yang memiliki INP tertinggi berturut-turut dari yang terbesar adalah $P$. firma, $S$. wallichii, $T$. wallichii, $P$. roxburghioies, $X$. petiolatus, dan $P$. pergracilis. Pada tingkat tiang, jenis yang memiliki INP tertinggi berturut-turut dari yang terbesar adalah $S$. walichii, Shorea sp., Cryptocarya sp., $P$. pinnata, $P$. roxburghioies, dan $S$. macrophylla. Pada tingkat pohon, jenis yang memiliki INP tertinggi berturut-turut dari yang terbesar adalah S. walichii, S. mahagoni, Shorea sp., dan Cryptocarya sp. Pada lokasi hutan tanaman, jenis $F$. moluccana merupakan jenis yang dominan dan hanya jenis ini yang ditemukan di hutan tanaman ini sehingga INP nya mencapai $200 \%$ (untuk tingkat pancang) dan $300 \%$ (untuk tingkat tiang).

Indeks Nilai Penting (INP) ini digunakan untuk mengetahui dominansi atau penguasaan suatu jenis, dimana semakin tinggi nilai INP akan mengindikasikan bahwa jenis tersebut adalah jenis yang dominan di suatu areal. Dengan kata lain, INP juga dapat mengindikasi kemampuan adaptasi suatu jenis untuk tumbuh dan berkembang di lingkungan tersebut. Besarnya nilai INP suatu jenis dipengaruhi oleh nilai-nilai kerapatan relatif, frekuensi relatif, dan dominansi relatif (untuk tingkat pertumbuhan tiang dan pohon) yang mempunyai hubungan yang positif (Setiadi 2004). Dendang dan Handayani (2015) juga berpendapat bahwa Indeks Nilai Penting suatu jenis memberikan gambaran bahwa keberadaan jenis tersebut semakin stabil atau berpeluang untuk dapat mempertahankan pertumbuhan dan kelestarian jenisnya. Suatu jenis tingkat pohon dan tingkat tiang dapat dikatakan dominan jika INP $\geq 15 \%$, adapun pada tingkat pancang dan semai akan dominan jika memiliki INP $\geq 1 \%$ (Ferianita 2006). Beragamnya nilai INP ini menunjukkan adanya pengaruh lingkungan tempat tumbuh, suhu, kelembaban, kemampuan jenis berkompetisi dalam perebutan unsur hara, sinar

\begin{tabular}{cccc}
\hline Lokasi & Jenis Dominan & Kategori & Tingkat Pertumbuhan Dominan \\
\hline & Tetracera scandens & Tumbuhan Bawah & \\
Schima walichii & Semai & Semai dan Pancang \\
Hutan Alam & Planchonella firma & Pancang & \\
& Schima walichii & Tiang & \\
& Schima walichii & Pohon & \multirow{2}{*}{ Pancang dan Tiang } \\
\hline \multirow{2}{*}{ Hutan Tanaman } & Falcataria moluccana & Pancang & Tiang \\
\hline
\end{tabular}


matahari, dan ruang tumbuh dengan jenis-jenis lainnya yang sangat memengaruhi pertumbuhan dari diameter suatu vegetasi dan aktivitas manusia yang bersentuhan langsung dengan hutan.

Pengaatan Tabel 2 menunjukkan bahwa secara umum tumbuhan pada areal lokasi hutan alam memiliki indeks dominansi jenis yang rendah karena nilainya mendekati 0 , sehingga hal ini mengindikasikan tidak adanya pemusatan jenis tertentu pada komunitas tumbuhan tersebut baik pada tingkat tumbuhan bawah, semai, pancang, tiang, dan pohon. Namun pada lokasi hutan tanaman, tingkat pertumbuhan pancang dan tiang ditemukan adanya pemusatan suatu jenis ( $F$. mollucana) dengan nilai $\mathrm{C}$ sebesar 1 . Terjadinya pemusatan suatu jenis pada tingkat pertumbuhan pancang dan tiang ini disebabkan adanya suatu jenis yang yang ditemukan dalam jumlah yang banyak sehingga mempunyai kerapatan yang besar, merata di hampir semua plot pengamatan dan mempunyai diameter yang lebih besar jika dibandingkan dengan jenis yang lain (Susanti dan Kusmana 2015).

Biodiversitas dapat diukur berdasarkan tiga komponen yaitu Indeks Keanekaragaman Jenis (H'),
Indeks Kemerataan Jenis (E), dan Indeks Kekayaan Jenis (R) (Magurran 1988). Berdasarkan Tabel 2 menunjukkan bahwa pada lokasi hutan alam memiliki kemerataan jenis yang tinggi pada semua tingkat pertumbuhan sedangkan pada hutan tanaman tergolong rendah karena komposisinya yang homogen atau satu jenis. Sehingga jenis-jenis yang ditemukan di hutan alam tergolong merata atau tersebar pada areal tersebut, dimana semakin merata jumlah individu masing-masing jenis yang ditemukan di suatu areal maka akan semakin merata dan melimpahnya jenis tersebut. Nilai indeks kekayaan jenis pada hutan alam tergolong rendah sampai sedang, sedangkan di hutan tanaman tergolong rendah. Secara umum data tersebut menunjukkan bahwa lokasi hutan mempunyai kekayaan jenis yang lebih tinggi jika dibandingkan dengan lokasi hutan tanaman. Hal ini dibuktikan dengan jumlah jenis yang ditemukan pada lokasi hutan alam yang lebih banyak daripada hutan tanaman. Magurran (1988) menyatakan bahwa kekayaan jenis akan meningkat seiring dengan semakin banyaknya jenis yang teridentifikasi, dan seiring meningkatnya ukuran sampel.

Keanekaragaman jenis mempunyai hubungan yang

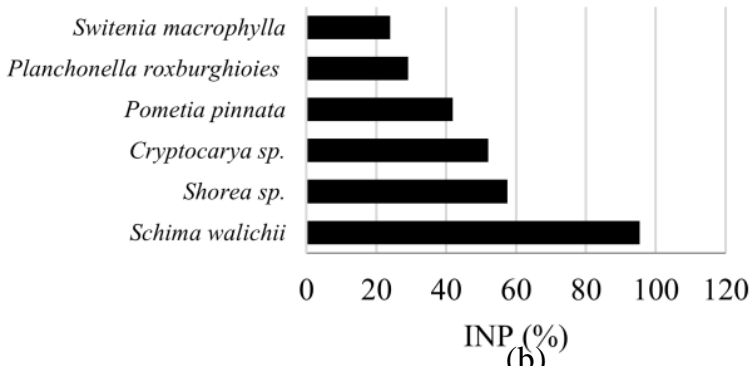

(b)

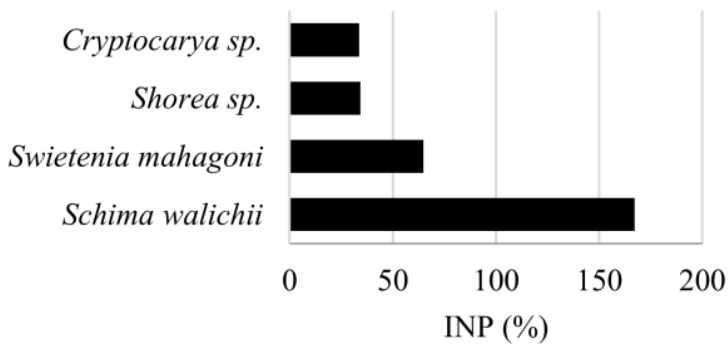

(d)

Gambar 1 Nilai INP di lokasi hutan alam pada tingkat pertumbuhan (a) semai dan tumbuhan bawah, (b) pancang, (c) tiang, dan (d) pohon

Tabel 2 Rekapitulasi analisis indeks keanekaragaman, kemerataan, kekayaan, dan dominansi

\begin{tabular}{clcccccccc}
\hline Tipe Hutan & Tingkatan & $\mathrm{H}^{\prime}$ & Kriteria & $\mathrm{E}$ & Kriteria & $\mathrm{R}$ & Kriteria & C & Pemusatan \\
\hline \multirow{5}{*}{ Hutan Alam } & Semai & 1.97 & Sedang & 0.73 & Tinggi & 2.61 & Rendah & 0.23 & Tidak Ada \\
& Pancang & 1.90 & Sedang & 0.63 & Tinggi & 4.22 & Sedang & 0.20 & Tidak Ada \\
& Tiang & 1.63 & Sedang & 0.91 & Tinggi & 1.89 & Rendah & 0.22 & Tidak Ada \\
& Pohon & 1.00 & Rendah & 0.72 & Tinggi & 0.89 & Rendah & 0.47 & Tidak Ada \\
\hline \multirow{5}{*}{ Hutan Tanaman } & Semai & - & - & - & - & - & - & - & - \\
& Pancang & 0.00 & Rendah & 0.00 & Rendah & 0,26 & Rendah & 1,00 & Ada \\
& Tiang & 0.00 & Rendah & 0.00 & Rendah & 0,00 & Rendah & 1,00 & Ada \\
& Pohon & - & - & - & - & - & - & - & - \\
\hline
\end{tabular}


erat dengan kekayaan jenis yang juga dipengaruhi dengan kondisi penyebaran/kemerataan suatu jenis tersebut (Magurran 1988). Semakin banyaknya jenis yang ditemukan dan dengan tingkat kemerataannya tinggi dalam suatu areal dapat mengindikasi bahwa areal tersebut mempunyai keanekaragaman jenis yang tinggi pula. Nilai indeks keanekaragaman jenis ini juga dapat menggambarkan produktivitas ekosistem, kestabilan, dan kondisi tekanan ekosistem. Dengan kata lain, apabila nilai H' berkisar antara 1-3 maka mengindikasi bahwa areal tersebut memiliki keanekaragaman yang sedang, produktivitas yang cukup, kondisi ekosistem yang cukup seimbang dan tekanan ekologisnya sedang. Namun, apabila nilai H' lebih dari 3 maka mengindikasikan bahwa areal tersebut memiliki keanekaragaman dan produktivitas yang tinggi dan stabilitas ekosistem yang mantap. Nilai indeks keanekaragaman jenis pada Tabel 2 telah menunjukkan bahwa hutan alam mempunyai keanekaragaman jenis yang lebih tinggi pada setiap tingkat pertumbuhannya dibandingkan dengan hutan tanaman.

\section{Analisis Sifat Tanah}

Tanah tersusun oleh bahan padatan, air dan udara. Bahan padatan ini meliputi bahan mineral berukuran pasir, debu, liat serta bahan organik. Bahan organik tanah biasanya menyusun sekitar 3-5\% dari total bobot tanah, meskipun hanya sedikit tetapi memegang peranan yang sangat penting dalam menentukan kesuburan tanah baik secara fisik, kimiawi maupun secara biologis tanah. Sumber primer bahan organik tanah adalah jaringan organik tanaman, baik berupa daun, batang/cabang, ranting, buah maupun akar (Barros dan Feranside 2016), sedangkan sumber sekunder berupa jaringan organik fauna termasuk kotorannya serta mikroflora (Hanafiah 2007).

Hardjowigeno (2010) menjelaskan bahwa kandungan organik tanah diukur berdasarkan kandungan C-organik dan mengalikannya dengan angka konversi sebesar 1.74. Tabel 3 menunjukkan bahwa semakin tinggi nilai C-organik tanah maka akan mengindikasikan nilai bahan organik tanah yang tinggi pula. Faktor-faktor yang memengaruhi kadar bahan organik tanah adalah jenis dan tekstur tanah, $\mathrm{pH}$ (Paz et al. 2016), kedalaman tanah, iklim, dan kondisi vegetasi yang ada di atasnya (Adams et al. 1990; Barchia 2009; Buczko et al. 2017; Hardjowigeno 2010; Notohadiprawiro 1998; Supardi 1983). Hal ini sesuai dengan data pada Tabel 3 yang menunjukkan bahwa pada lokasi pasca tambang yang tanpa vegetasi memiliki C-organik yang lebih kecil daripada dua lokasi lainnya yang bervegetasi.

Brachia (2009) dan Notohadiprawiro (1998) menyebutkan bahwa kondisi vegetasi di atas tanah berpengaruh pada nilai bahan organik tanah (melalui nilai C-organik), yaitu pada hutan hujan tropika mempunyai C-organik yang lebih rendah dari pada hutan iklim sedang dan padang rumput, yaitu secara berurutan nilainya adalah 80 ton/ha, 100 ton/ha, dan 150 ton/ha. Hutan mempunyai kadar bahan organik yang lebih tinggi disertai nisbah $\mathrm{C} / \mathrm{N}$ yang tinggi pula, sehingga proses dekomposisi lambat, selain itu hutan tropika mempunyai elevasi berbeda dan sangat berkaitan dengan suhu. Faktor suhu sangat berpengaruh pada proses dekomposisi/mineralisasi bahan organik, yaitu semakin tinggi suhu maka proses dekomposisi semakin lemah karena kegiatan jasad pengurai menurun.

Bahan organik tanah sangat berpengaruh terhadap sifat fisik dan kimia tanah. Supardi (1983) menjelaskan bahwa bahan organik akan memengaruhi ciri tanah yaitu (1) berpengaruh terhadap warna tanah menjadi lebih coklat sampai dengan hitam, (2) dapat merangsang granulasi, menurunkan plastisitas, kohesi dan meningkatkan kemampuan menahan air, (3) meningkatkan daya jerap kation mencapai 20 sampai dengan 30 kali dari koloid mineral, (4) memudahkan dalam pertukaran kation dan mengindikasikan tanah yang subur. Penelitian Grigal dan Vance (2000) menunjukkan bahwa bahan organik tanah mempunyai hubungan yang erat dengan kepadatan tanah (bulk density), yang mana semakin tinggi kandungan bahan organik tanah maka dapat menurunkan kepadatan tanah. Selain itu, penambahan BOT pada tanah bertekstur pasir, liat dan lempung dapat meningkatkan ketersediaan air dalam tanah.

Tabel 3 Kondisi sifat fisik dan kimia tanah di lokasi pengamatan

\begin{tabular}{|c|c|c|c|c|c|c|c|}
\hline \multirow{3}{*}{ Parameter } & \multirow{3}{*}{ Satuan } & \multicolumn{6}{|c|}{ Lokasi } \\
\hline & & \multicolumn{2}{|c|}{ Hutan Alam } & \multicolumn{2}{|c|}{ Hutan Tanaman } & \multicolumn{2}{|c|}{ Lahan Pasca Tambang } \\
\hline & & Nilai & Kriteria & Nilai & Kriteria & Nilai & Kriteria \\
\hline C-Organik & $\%$ & 1.39 & $\begin{array}{l}\text { Sangat } \\
\text { Rendah }\end{array}$ & 0.39 & $\begin{array}{l}\text { Sangat } \\
\text { Rendah }\end{array}$ & 0.21 & Sangat Rendah \\
\hline $\mathrm{Ca}$ & $\mathrm{cmol} / \mathrm{kg}$ & 1.05 & Rendah & 0.40 & Rendah & 0.38 & Rendah \\
\hline $\mathrm{Mg}$ & $\mathrm{cmol} / \mathrm{kg}$ & 0.95 & Sedang & 0.30 & Rendah & 0.45 & Sedang \\
\hline KTK & $\mathrm{cmol} / \mathrm{kg}$ & 10.43 & Rendah & 7.47 & Rendah & 5.22 & Rendah \\
\hline $\mathrm{pH}$ & & 6.38 & Sedang & 5.33 & Rendah & 5.12 & Rendah \\
\hline KB & $\%$ & 25.80 & Sedang & 16.07 & Rendah & 13.01 & Rendah \\
\hline Bulk Density & $\mathrm{g} / \mathrm{cm}^{3}$ & 1.31 & Tinggi & 1.02 & Sedang & 0.84 & Rendah \\
\hline Porositas & $\%$ & 50.57 & & 61.51 & & 68.30 & \\
\hline
\end{tabular}




\section{SIMPULAN}

Hutan alam yang diamati memiliki jenis dominan yang berbeda-beda tiap tingkat pertumbuhan dan setiap titik pengamatannya. Hutan tanaman yang diamati hanya didominasi oleh satu jenis saja sehingga nilai Indeks Keanekaragaman Jenis, Indeks Kekayaan Jenis, dan Indeks Kemerataan Jenis pada hutan alam lebih tinggi daripada hutan tanaman. Indeks Dominasi Jenis yang sebagian besar mendekati nol menunjukkan tidak adanya dominansi oleh suatu jenis pada lokasi pengamatan di hutan alam, sedangkan di hutan tanaman terjadi pemusatan jenis. Dari aspek tanah, terlihat bahwa pada lahan pasca tambang nikel memiliki kesuburan yang rendah karena sifat pertambangannya yang terbuka sehingga lapisan atas tanah di areal tersebut menjadi hilang.

\section{SARAN}

Pada lahan revegetasi (hutan tanaman) perlu dilakukan pengayaan jenis endemik untuk tumbuhan bawahnya

\section{DAFTAR PUSTAKA}

Adams JM, Faure H, Faure-Denard L, McGlade JM, Woodward FI. 1990. Increases in terrestrial carbon storage from Last Glacial maximum to the present. Nature. 348:711-714.

Ahmad F. 2009. Tingkat Pencemaran Logam Berat dalam Air Laut dan Sedimen di Perairan Pulau Muna, Kabaena, dan Buton Sulawesi Tenggara. Makara, Sains. 13(2):117-124.

[BSN] Badan Standarisasi Nasional (ID). 2011. SNI 7724:2011:Pengukuran dan Perhitungan Cadangan Karbon - Pengukuran Lapangan untuk Penaksiran Cadangan Karbon Hutan (Ground based Forest Carbon Accounting). Jakarta (ID): Badan Standarisasi Nasional.

Barchia MF. 2009. Agroekosistem Tanah Mineral Asam. Yogyakarta (ID): Gadjah Mada University Press.

Barrors HS, Fearndise PM. 2016. Soil carbon stock due to edje effects in central Amazon forest fragments. Forest Ecology and Management. 379:30-36.

Buczko U, Kohler S, Bahr F, Scharnweber T, Wilmking M. 2017. Variability of soil carbon stocks in a mixed forest on hydromorphic soils. Geoderma. 307:8-18.

Dendang B, Handayani W. 2015. Struktur dan komposisi tegakan hutan di Taman Nasional Gunung Gede Pangrango, Jawa Barat. PROS SEM NAS MASY BIODIV INDON. 1(4):691-695.

[ESDM] Kementerian Energi dan Sumber Daya Mineral (ID). 2015. Dampak Pembangunan Smelter di Kawasan Ekonomi Khusus Provinsi Sulawesi Tenggara. Jakarta (ID): Pusat Data Dan Teknologi Informasi Energi dan Sumber Daya Mineral.
Ferianita M. 2006. Metode Sampling Bioekologi. Jakarta (ID): Bumi Aksara.

Grigal DF, Vamce ED. 2000. Influence of soil organic matter on forest productivity. New Zealand Journal of Forestry Science. 30(1/2):169-205.

Hanafiah KA. 2007. Dasar-Dasar Ilmu Tanah. Jakarta (ID): PT Raja Grafindo Persada.

Hardjowigeno S. 2010. Ilmu Tanah. Jakarta (ID): Akademika Presindo.

Indrayatie ER. 2011. Dampak Pasca Penambangan Intan Terhadap Kualitas Tanah dan Air Di Kelurahan Palam Kecamatan Cempaka Kota Banjarbaru Kalimantan Selatan. J Hutan Tropis. 12(31):15-25.

Indriyanto. 2006. Ekologi Hutan. Jakarta (ID): PT Bumi Aksara.

Landon JR. 1984. Booker Tropical Soil Manual. London (EN) dan New York (US): Booker Agriculture International Limited.

Magurran AE. 1988. Ecological Diversity and Its Measurement. Australia (AU): Croom Helm.

Mueller-Dombois D, Ellenberg H. 1974 Aims and Methods of Vegetation Ecology. New York (US): J Wiley.

Notohadiprawiro T. 1998. Tanah dan Lingkungan. Jakarta (ID): Direktorat Jenderal Pendidikan Tinggi Departemen Pendidikan dan Kebudayaan.

Paz CP, Goosem M, Bird M, Preece N, Goosem S, Fensham R, Laurance S. 2016. Soil types influence predictions of soil carbon stock recovery in tropical secondary forest. Forest Ecology and Management. 376:74-83.

Setiadi D. 2004. Keanekaragaman spesies tingkat pohon di Taman Nasional Alam Ruteng, Nusa Tenggara Timur. Biodiversitas. 6(2):118-122.

Setiadi Y. 2012. Bahan Kuliah Ekologi Restorasi. Program Studi Ilmu Pengetahuan Kehutanan, Sekolah Pasca Sarjana, IPB. Tidak Diterbitkan.

Soerianegara I, Indrawan A. 1998. Ekosistem Hutan Indonesia. Bogor (ID): Fakultas Kehutanan IPB.

Supardi G. 1983. Sifat dan Ciri Tanah. Bogor (ID): IPB Press.

Susanti S, Kusmana C. Komposisi dan struktur tegakan hutan alam di hutan pendidikan Gunung Walat, Sukabumi. Jurnal Silvikultur Tropika. 5(3): 210217.

Widiatmaka, Suwarno, Kusmaryandi N. 2010. Karakteristik Pedologi dan Pengelolaan Revegetasi Lahan Bekas Tambang Nikel: Studi Kasus Lahan Bekas Tambang Nikel Pomalaa, Sulawesi Utara. J Tanah dan Lingkungan. 12(2):1-10.

Yudhistira. 2011. Kajian Dampak Kerusakan Lingkungan Akibat Kegiatan Penambangan Pasir di Desa Keningar Daerah Kawasan Gunung Merapi. Jurnal Ilmu Lingkungan. 9(2):76-84. 